THURSDAY, JUNE I5, I916.

\section{POSITION AND PROSPECTS OF} CHEMICAL INDUSTRY.

RECENT communications to the British and R German Press show that already the opposing forces of the trade war of the near future are manœuvring into positions favourable for the prosecution of their militant operations. This contest, when opened, will be most severe in the domain of the coal-tar products, in which hitherto the German manufacturers have maintained a very lucrative monopoly. The German newspapers of the first week in May contain references to an amalgamation of the producers of aniline dyes, drugs, and other fine chemicals. These manufacturers, who have made enormous profits since the outbreak of war, have been impelled to take this step by the fear of foreign, and especially British and American, competition. Seven large chemical factories formerly belonging to three different groups have, while retaining a certain degree of independence, formed a new "community of interests," in which the units will share their "experience," so that all products will be manufactured by at least two of them simultaneously. The strength of this amalgamation is to be gauged, not only by its capital of more than I , ooo,oool., but by its unequalled combination of financial, technical, and scientific efficiency.

The advocates of a chemical directorate for chemical factories are met in England with the statement that in Germany the technical directors are only apparently supreme, and that the higher policy is in reality dictated by bankers and financiers. This view is contradicted by Vorwärts, which states that the German chemical trust is the only one over which banks and financiers have no control, because this chemical industry has always made such huge profits that it is now supplied with ample funds for extension. The German Press is very optimistic as to the success of the new organisation in maintaining the ascendancy in dyes and fine chemicals of all descriptions. This sanguine anticipation is based on the fact that chemical science has hitherto been treated with indifference in England. The Neueste Nachrichten of Munich asks, "Do the English really believe that, by means of customs and patent laws, by waging an economic war, and by boycotting our goods, they can counterbalance German intelligence?" Vorwärts, from the point of view of the worker, deplores the formation of the German trust on the ground that a chemist or chemical workman incurring the displeasure of one unit of the group is not likely NO. 2433, VOL. 97] to find further employment in German chemical industry.

In England the situation in regard to the grouping of coal-tar industries is still obscure, but certain significant developments have recently taken place. The State-fostered organisation has at length admitted a chemist to its board of directors, a step the desirability of which has been repeatedly urged in the columns of NATURE and other organs of the Press. But although British Dyes, Ltd., of Huddersfield, have in the diffcult circumstances of the war made commendable progress, it is hard to see how this single organisation can hope to compete with the giant trust of Germany, with its vast resources and accumulated experience. Government help should be forthcoming for all willing workers in this field, and attempts at the boycott and repression of individual firms or chemists should, in the public interest, be rigorously suppressed. The friendly rivalry between Yorkshire and Lancashire, which is a perennial feature of life in the industrial North, is being extended into chemical industry by the recent noteworthy achievements of the firm of Messrs. Levinstein, Ltd., of Manchester. Although excluded from the Governmental favours monopolised by their trade rivals, this firm now claims to manufacture one-half the quantity of dyes formerly imported into this country from Germany. Throughout the war Messrs. Levinstein have supplied the Admiralty and War Office with enormous quantities of blue and khaki dyes, and their colours have rendered possible the equipment of the Belgian and Italian armies with dyed uniforms. The scientific side of this enterprise will be greatly strengthened and vitalised by the appointment to the headship of its research department of Prof, Green, formerly professor of tinctorial chemistry in the University of Leeds, and the discoverer of primuline, dianthine, and other important dyes.

In addition to the two oldest-established firms, many other industrial undertakings are developing extensively in the direction of manufacturing dyes and other coal-tar products. These firms include, not only those in the colour trade before the war, but also munitions factories at present engaged in the production of high explosives, the directors of which are looking to the manufacture of dyes and fine chemicals for a profitable employment of their numerous workers and extensive plants. Finally, there is an increasing tendency on the part of academic chemists to launch out in the direction of preparing urgently needed chemicals, such as dimethylaniline and $\beta$-naphthol. Some of these workers are spending time and money on products which are already being successfully manu- 
factured by the larger firms. During the war period the famine in chemicals enables the "small men" to make a profit, even on their necessarily restricted operations. It is, however, doubtful whether these praiseworthy enterprises will be able to withstand the stress of the forthcoming trade war. The collapse of these smaller undertakings will spell ruin to some, and will inevitably entail losses of capital and industrial energy. What is urgently needed at present is an intelligent co-ordination of these useful and patriotic activities.

The question of dyes is only part of the larger problem of coal-tar products, in which Germany has invested a capital of $80,000,000 l$. The cost of producing the best modern synthetic dyes can never in this country be brought to the German level until the utilisation of numerous by-products is placed on a sound economic basis. The solution of this intricate problem demands years of patient and often unproductive research, systematic organisation of chemical investigation, coordination of national resources in men and materials, and extensive industrial development, supported and defended impartially by a scientifically informed branch of the Government.

There is no evidence that anything systematic is being attempted. These sporadic and disorganised enterprises will prove futile against our scientifically organised opponents. Success in this strenuous struggle will come to British chemical industry only if the tactics of the unsupported industrial sniper are replaced by the farseeing strategy of an organised general staff of qualified chemists and manufacturers.

An important step in this direction was taken on May 23 at a meeting, held at Burlington House, of the representatives of one hundred leading firms engaged in chemical industries, when a motion was adopted to the effect that "it was desirable that British firms engaged in the chemical and allied trades should form an association to promote closer co-operation and to place before the Government the views of the chemical trade generally; to further industrial research; and to facilitate closer co-operation between chemical manufacturers and various universities and technical schools."

At this meeting the chairman, Dr. Charles Carpenter, president of the Society of Chemical Industry, pointed out that at present we had no organisation to meet foreign competition when war was over. Mr. Brunner, M.P., mover of the resolution, stated that, although the war had shown that science was invaluable in time of war, yet the Government, by their lack of knowledge of chemistry, had kept them back in more ways than one.

$$
\text { NO. } 2433 \text {, voL. } 977
$$

The opinion was also expressed that this organisation of chemical industries should be regarded as a necessary step in the direction of affiliating chemical manufacturers with a more comprehensive union embracing allied trades. How extensive and diverse are the ramifications of the colour industry will be seen when due consideration is given to the trades affected directly by the abnormal price of dyes. Although textile manufacturers have been hardest hit, the blow has also been felt by paint- and colour-makers, papermakers, ink-manufacturers, leather-workers, soapboilers, coach-builders, sealing-wax makers, and the linoleum, celluloid, and engineering trades. If further evidence be needed to emphasise the claim of the synthetic dye manufacturers for impartial and extensive Government support, it is the cardinal fact that this trade is a key industry in the general scheme of national defence. An outstanding example may be cited. One of the large German dye groups was, before the war, employing 10,000 operatives in the production of colours and other fine chemicals. To-day there are 14,000 workers in these factories making high explosives.

\section{LAMB'S HYDRODYNAMICS.}

Hydrodynamics. By Prof. Horace Lamb. Pp. xvi +708 . Fourth edition. (Cambridge: At the University Press, 1916.) Price $24 s$. net.

THAT this work should have already reached a fourth edition speaks well for the study of mathematical physics. By far the greater part of it is entirely beyond the range of the books available a generation ago; and the improvement in the style is as conspicuous as the extension of the matter. My thoughts naturally go back to the books in current use at Cambridge in the early 'sixties. With rare exceptions, such as the notable one of Salmon's "Conic Sections," and one or two of Boole's books, they were arid in the extreme, with scarcely a reference to the history of the subject treated or an indication to the reader of how he might pursue his study of it. At the present time we have excellent books in English on most branches of mathematical physics, and certainly on many relating to pure mathematics.

The progressive development of his subject is often an embarrassment to the writer of a textbook. Prof. Lamb remarks that his "work has less pretensions than ever to be regarded as a complete account of the science with which it deals. The subject has of late attracted increased attention in various countries, and it has become correspondingly difficult to do justice to the growing literature. Some memoirs deal chiefly with questions of mathematical method and so fall outside the scope of this book; others, though physically important, scarcely admit of a condensed analysis; others, again, owing to the multiplicity 